\title{
The Senior Independent Director's Evolving Role Across the Top 100 Malaysian PLCs: MCCG 2012 vs MCCG 2017
}

\author{
Dayana Mastura Baharudin \\ Department of Accounting, School of Management \\ Universiti Sains Malaysia \\ Minden, 11800, Penang, Malaysia \\ Maran Marimuthu \\ Department of Management and Humanities \\ Faculty of Science and Information Technology \\ Universiti Teknologi PETRONAS, 32610, Seri Iskandar, Perak, Malaysia
}

Received: Aug. 31, 2020 Accepted: Sep. 23, 2020 Published: Sep. 29, 2020

doi:10.5296/bms.v11i2.17602 URL: https://doi.org/10.5296/bms.v11i2.17602

\begin{abstract}
Purpose - This research aims to investigate the impact of the two main problems of Senior Independent Director's evolving role, which includes the aspects under board leadership and board effectiveness proposed under the Malaysian Corporate Governance Code (Code) in contrast between 2012 and 2017 towards firm financial performance.

Design/ methodology approach - For this analysis, a target list of the top 100 PLCs based on market capitalization was gathered from 784 Malaysian PLCs as of 14 August 2020. In the annual review of corporate reports, this research involves mean and standard deviation, analysis of the correlation and analysis of the materials published within the annual reports.

Originality - This report is a comprehensive examination of the recent developments in Corporate Governance research in comparison between the Code in 2012 and 2017, which is also applicable to other PLCs other than the top 100 Malaysian PLCs scoring indices designed for the Senior Independent Director - Board Effectiveness and Board Leadership.
\end{abstract}


Keywords: Senior independent director, Board effectiveness, Board leadership, Malaysian governance practices, Financial success

\section{Introduction}

International corporate dynamics are under progress in the post-Enron period to bring about a better power structure in the company, currently ruled by overly strong leaders, to resolve dominance conflicts among the interested parties. Executive leadership structures have different mechanisms to assure organisations' productive activity and maximise the value of investors. The effective corporate regulation, firstly, aims to direct management towards client needs, as well as national laws such as the Sarbanes-Oxley Act (SOX) 2002, which sets general managers, auditing companies and boards new obligations to resolve conflict of interest and improve company transparency. Structurally, the Board of Directors are delegated with the internal corporate regulation. Board members are, by default, an effective internal control mechanism that forms corporate governance, provided their total connection to other two dimensions of the corporate governance equation - managers and owners are in equilibrium. The Board of Directors are among the key elements required in the restructuring of corporate governance practiced by the organisation. Evidently, the Board of Directors appeared as both a point of responsibility for corporate frauds and a point of capability in strengthening corporate governance within the organisation.

\section{Problem Statement}

The presence of external directors, representing the board independence and its effect on the consistency of the oversight of the Board, is a key issue for governance practices. Awareness has grown after the globally known corporate scandals involving Enron, WorldCom and Tyco International which reflected the lack of successful board oversight in these companies. Consequently, in July 2002, the Sarbanes-Oxley Act required company audit committees to be made up completely of independent directors. This is in congruence with the law approved by the Securities and Exchange Commission in 2003 by the New York Stock Exchange (NYSE) and the National Association of Securities Dealers Automatic Quotation System (NASDAQ) which also required a variety of external directors reflecting autonomous board positions, and an audit committee.

In the long run, the tenure of independent directors grew over time, with the average tenure of independent directors from 2010 to 2014 being seven years, compared to six years in the 2000-2009 period and five years in previous years. These statistics shows that independent directors are fast becoming the role of inside directors with a mere label as independent due to the increasing length of their contract with an organisation which eventually will breed complacence.

The top 30 percentile of the term is 10 years, and the lowest 30 percentile is equal to three years for independent directors of all sample companies across the whole sample period, which still suggests an unprecedented rate of extension of the tenure of independent directors (Gao and Huang, 2017). 
A Senior Independent Director is described as persons with tenure of over 10 years, and junior independent directors as persons with tenures of less than 3 years. The era of the 1990s encompasses 1998 and 1999 where all independent directors had a median term of five years. The year 2000-2004, is the first period under review, and the second period under review covered the year 2005-2009. The median term of office of all independent directors during these two review periods are also six years. Then from 2010 to 2014 all independent directors had a median tenure of seven years in this period (Gao and Huang, 2017).

In conclusion, the tenure of the independent directors have increased from a median of 5 years in the 1990s to 7 years in 2014, which is questionable on the true meaning of independence, as independence would be best practiced if the tenure is only awarded from 13 years. The tenure of more than 3 years would instigate favouritism or prejudice practices amongst the independent directors.

Furthermore, the tenure given to the Senior Independent Directors are usually longer compared to the tenure given to the Independent Directors, maybe due to the level of seniority which deems of high importance. Therefore when the Senior Independent Directors should be practising high objectivity and independence, their employment contract of more than 3 years does not reflect such independence. Other extravagant cases includes the case of the promotion of the Independent Director to the post of Senior Independent Director which prolonged the employment contract to maybe 10 years or more.

In addition, the number of senior independent directors classified as over 10 years of contractual service representing the top 30 percentile in 1998 of all independent directors, increased slightly further in 2005, with the proportion of senior independent directors increasing further from 29 percent in 2005 to 37 percent in 2014. In contrast, the number of junior independent directors with a relatively low 30 percentile term of office decreased from 35 percent in 2005 to 24 percent in 2012 and only bounced back to 27 percent in 2014 .

The increasing length of the employment contract of the independent directors would trigger a dramatic change as it clearly does not reflect independence to the stakeholders and demonstrates advocacy threat, potentially due to the limited range of skills and the difficulty of finding the right director in the corporate world.

Companies prefer to maintain long-term autonomous directors in order to fulfil the requirements for independent directors which clearly breeds advocacy and bias, since it is impossible or costly to find alternative directors which are in line with the low turnover of independent directors amongst the two-thirds of the S\&P 500 companies, according to Francis and Lublin (2016). It is also the practice of internal directors or executive directors to select their friends to become the independent directors of their organisation, as although the independent director's role is to uphold independence and objectivity but in reality, these independent-director-friends will always support their employer activities and decisions despite the occurrence of irregularities. 


\section{Research Objectives}

Research objective 1: To examine the effect of the degree of publication of the evolving role of the Senior Independent Director - Board Effectiveness in achieving the financial results of the top 100 Malaysian PLCs contrasting between the Corporate Governance practices in 2012 and the 2017.

Research objective 2: To examine the effect of the degree of publication of the evolving role of the Senior Independent Director - Board Leadership in achieving the financial results of the top 100 Malaysian PLCs contrasting between the Corporate Governance practices in 2012 and the 2017.

\section{Research Questions}

Research Question 1: Does the degree of publication of the evolving role of the Senior Independent Director - Board Effectiveness, contrasting between the Corporate Governance practices in 2012 and the 2017 have impact on the financial results of the top 100 Malaysia PLCs?

Research Question 2: Does the degree of publication of the evolving role of the Senior Independent Director - Board Leadership, contrasting between the Corporate Governance practices in 2012 and the 2017 have impact on the financial results of the top 100 Malaysia PLCs?

\section{Literature Review}

\section{Senior Independent Director - Board Leadership and Effectiveness}

In practice note 1.3 and 4.1, the Code of 2017 acknowledged the Board as consisting of three distinct members, the Chairman, the Executive Officers (headed by the CEO or the Management Board) and the Senior Independent Director.

The position of the Chairman of the board of directors and the CEO should be performed by two different individuals under the 2017 Code - Practice note 1.3. In this relationship, segregation is necessary, as the two roles have their own chosen audiences and requirements. When the organisation recruits an Executive Chairman, there should be guidelines to foster higher reliability in the Board.

The provision for practice note 4.1 of the Code of 2017 provides for an intrinsic requirement that in minimum, there should be $50 \%$ of the board comprised of independent directors. Large companies reiterated as reported in Code of 2017 that more than 50\% independent directors should be part of the board composition to reflect independence.

Securities Commission Malaysia $(2012$; 2017) provides for more efficient control of the administration by a $50 \%$ composition of independent directors. This will promote critical and unbiased deliberation, analysis and decision-making.

Moreover, businesses may consider naming a senior independent director as the chairman's 
sounding board and leading the chairman's performance assessment. Especially in cases in which the Chair and CEO are part of the close family, the recruitment of the senior independent director may encourage objectivity (Securities Commission Malaysia, 2017).

MCCG 2017 under practice note 4.7 notes that an Independent Director or Senior Independent Director may lead the appointing committee. In the recruitment of directors, the Nominating Committee reviews the executive performance and guides the board's ongoing progress.

In terms of effectiveness of control, the board is also regarded as having three main players of which the first being the chairman in a supervisory role, the second being executive management which is headed by the managing director to perform the tasks of an agent in the principal-agent relationship, and thirdly the external directors, whose charismatic leader is the senior independent director to monitor the agents daily activities in order to report back to the owners.

Senior Independent Director's evolutionary role is described in three parts, the first which is included in the Code of year 2000 which formalized the position of the nominating committee and its non-executive membership without any clear direction yet. Secondly and progressively, it involved the rules within the Code of 2007 and 2012 which continued to emphasize the growing important position of the nominating committee which have not gained any traction amongst the PLCs. The third and final part includes the rules of the latest Code of 2017, which strengthened the structure of the Nominating Committee where it demanded an Independent Director or Senior Independent Director to lead the Nominating Committee as a stricter form of control (Securities Commission Malaysia, 2012; 2017).

In order to give businesses more flexibility, the Code of 2017 purposely avoided the rule to select just the Senior Independent Director as the nominating committee's preferred chief. However, another independent representative may also be more useful in serving as Chief of the appointing committee under other circumstances.

The Senior Independent Director, for example, may believe that, without the tasks of a Board Committee, independence should really be difficult to be maintained and other independent directors should express their opinion in the best possible way possible through the Committee.

The question remains as to whether an independent director or the Senior Independent Director should head the Nomination committee. However, it should be recognized that as the chairperson of the Nominating Committee, the position of a Senior Independent Director lies also in influencing the evaluation of the Chairman of the Board.

As the senior independent director generally acts as an advisor to the other executives, he or she is well placed to control the assessment of the board 's chairman, taking into account a broad range of opinions.

In turn, a senior independent director is also responsible for other conventional positions, such as providing guidance to the Chairman on topics such as board complexities and issues of interested parties, in overseeing the nominating committee; serving as a middleman, where 
applicable, for other directors such as facilitating discreet talks with directors who may have concerns they feel the board has not fully addressed or which may have not been sufficient to address directly in the public discussion or with the President; strategy as point of reference, particularly with regard to matters not resolved through the regular process of dealing with the Chairperson or Chief Executive, for owners and other parties concerned; offer leadership information and advice to the Board in cases of friction, such as conflicts between the President and CEO, or any follow-up plans; the continuity management and recruitment of Board members including the potential Chairman and CEO; and the execution of an ongoing analysis of the effectiveness of the Board ensuring that the member has an unbiased and thorough evaluation of his performance, as all directors' opinions are impartially acquired (Securities Commission Malaysia, 2018).

Therefore, a popular misconception of the importance of senior independent directors in publicly-listed corporations involves the position in which creates them to elect the oldest independent director which have served the lengthiest time on the board which actually reflects non-independence despite the title of the post being a senior independent director in the right capacity. In reality, attributes like transformational skills, expertise and industry or board experience must be considered by the committee to determine a director's fitness as a senior independent director. Given its complexities, the board is responsible for agreeing on this principle. Some jurisdictions consider the word "senior" to be an inappropriate designation and instead have preferred to name those directors as "lead independent director" (Securities Commission Malaysia 2017).

\section{Theoretical Framework}

\section{Agency theory}

This relationship between the Senior Independent Director - Board Effectiveness and Leadership, and the firm financial performance is endorsed by the Agency theory. It's unavoidable to see the link between the key agent (governance practices and its issues) when the philosophical goal is pursued.

The theory of agencies (Fama , 1980, Fama, and Jensen, 1983; Jensen \& Meckling, 1976) and stewardship theory (Davis et; al., 1997, Donaldson, 1990a, Donaldson, 1990b; Donaldson, 1991) are two philosophical constructs used to explain the subject and its consequent impact on firm results. The philosophies of the Agency assert that a conflict between people, such as board members and owners, is inevitable. Agent is mostly self-interested and unscrupulous and not selfless, as a consequence of an organisation's theory.

In the perspective of agency theories, when the Board of Directors is dominated by internal executives, problems with agencies will become more prominent (Bathala and Rao, 1995, Nicholason and Kiel, 2008; Zahra and Pearce, 1989).

Boards controlled by internal executive directors with overpowering attitudes may accrue control and responsibility which may weaken or reduce the overall surveillance performance of the organisation (Solomon, 2007). 


\section{Al Macrothink}

Business Management and Strategy

ISSN 2157-6068 2020, Vol. 11, No. 2

The self-interest can be motivated by powerful insiders, and self-serving practices that could affect the economic interests of directors which can be carried out unless otherwise limited (Deegan, 2006).

The separation of roles can make it possible for Boards, since such Boards are considered autonomous, which results in more successful exercise of their judicial functions (Finkelstein \& Mooney 2003).

The theory of agencies therefore implies that the board-'s independence has a positive relationship with corporate governance (Boyd, 1995).

In contrast, the philosophy of custodianship has a favourable view of human conduct (governance) which don't generally rely on individual objectives, are discreet and are not vulnerable to misappropriation, and are motivated to work for their directors' interests (Barney, 1990, Donaldson, 1990a, Donaldson, 1990b, Donaldson and Davis, 1991).

The study investigates whether the independence of the Board increases firm efficiency. The theoretical placement of this study is based on the theory of agency according to the purpose of this research.

\section{Conceptual Framework}

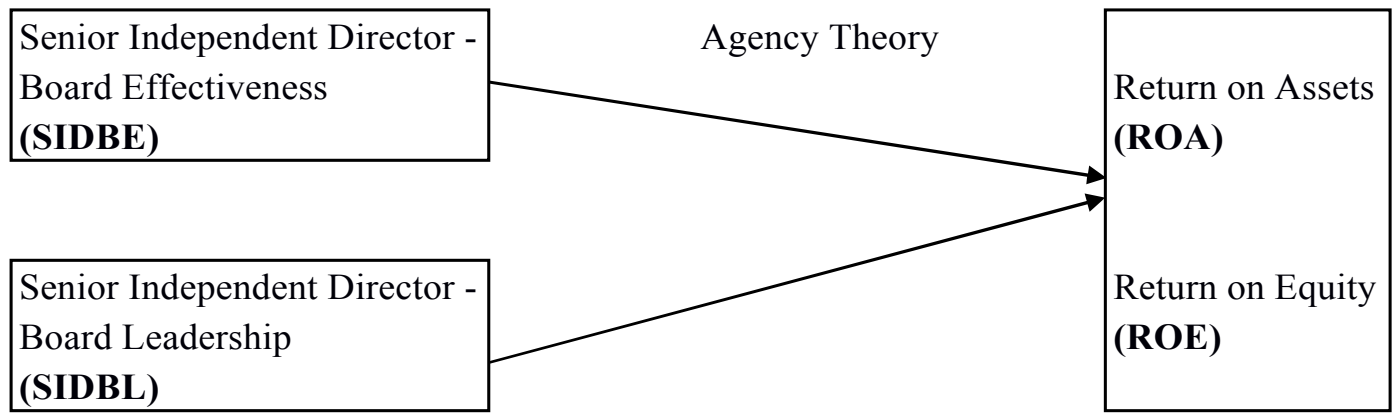

Controlled variables

Firm Age (AGE)

Firm Size (SIZE)

Figure 1. Conceptual Framework - Senior Independent Director

\section{Hypotheses Statements}

Hypothesis 1a: Senior Independent Director - Board Effectiveness has impact on firm financial results during the 2012 Code in which Return on Equity was based.

Hypothesis 1b: Senior Independent Director - Board Effectiveness has impact on firm financial results during the 2017 Code in which Return on Equity was based.

Hypothesis 1c: Senior Independent Director - Board Effectiveness has impact on firm financial results during the 2012 Code in which Return on Assets was based. 
Hypothesis 1d: Senior Independent Director - Board Effectiveness has impact on firm financial results during the 2017 Code in which Return on Assets was based.

Hypothesis 2a: Senior Independent Director - Board Leadership has impact on firm financial results during the 2012 Code period in which Return on Equity was based.

Hypothesis 2b: Senior Independent Director - Board Leadership has impact on firm financial results during the 2017 Code in which Return on Equity was based.

Hypothesis 2c: Senior Independent Director - Board Leadership has impact on firm financial results during the 2012 Code in which Return on Assets was based.

Hypothesis 2d: Senior Independent Director - Board Leadership has impact on firm financial results during the 2017 Code in which Return on Assets was based.

\section{Research models}

\section{Model 1:}

$\mathrm{ROE}=\beta 0+\beta 1 \mathrm{SIDBE}+\beta 2 \mathrm{SIDBL}+\beta 3 \mathrm{AGE}+\beta 4 \mathrm{SIZE}+\varepsilon$ it

Whereas:

$\mathbf{R O E}=$ Is a key financial metric measured by the net profits divided by the owners' equity of the top 100 Malaysian PLCs

ROA $=$ is a profitability ratio measuring the net revenue generated by asset value

SIDBE $=$ Senior Independent Director - Board Effectiveness

SIDBL $=$ Senior Independent Director - Board Leadership

AGE $=$ Firm Age

SIZE $=$ Firm Size

cit $=$ Error term

\section{Model 2:}

$\mathrm{ROA}=\beta 0+\beta 1 \mathrm{SIDBE}+\beta 2 \mathrm{SIDBL}+\beta 3 \mathrm{AGE}+\beta 4 \mathrm{SIZE}+\varepsilon \mathrm{it}$

\section{Context and Methods for the Research and Execution of Parameters}

In this analysis, the target sample of the top 100 PLCs market cap of the populace of 784 Malaysian public listed companies has been used as of 14 August 2020. This research demonstrates statistical analysis, linear regression and document analysis for the evaluation of annual reports. The 3-year data collected for this research will be obtained across 2016, 2017 and 2018. Year 2016 was selected due to the fact that the 2012 MCCG is still functional and in progress during that period. The year 2017 was selected as MCCG 2017 was launched in 2017, in which businesses are in the process of changing their corporate governance policies from MCCG 2012 to MCCG 2017 and the reforms introduced in MCCG 2017 were incredibly difficult to be adopted. The year 2018 was identified to see both the impact of the 
proposed in MCCG 2017 and to see that the new Code is likely to be implemented incrementally. As a result, taking these 3 years will allow the investigator to distinguish between MCCG 2017's pre-and post-results.

\section{Scoring Indices}

\section{Senior Independent Director Evolving Role: Board Effectiveness (3 items)}

- To support and give advice to the Chairman

- An intermediary for the Non-Executive Directors when necessary

- To ensure there is a clear division of responsibility between the Chairman and Chief Executive Officer

\section{Senior Independent Director Evolving Role: Board Leadership (4 items)}

- The point of contact for shareholders

- The point of contact for stakeholders

- The Board Nomination Committee should be chaired by the Senior Independent Director

- To lead the Non-Executive Directors in the oversight of the Chairman

\section{Significance of Study}

Over the years of survival during the turmoil following the Asian Currency Crisis in the late 1990s and the 2008 World Economic Crisis, the 2017 Code have advanced and improved from the first Code launched in 2000.

The Senior Independent Director - Board Effectiveness index comprise of three aspects which may be considered highly stringent for those PLCs that are not in the top 100 group but essentially for the benefit of none other than the PLC itself and its stakeholders if they can meet all three requirements.

Senior Independent Director - Board Leadership requires four elements of the requirements obtained from the 2017 Malaysian Corporate Governance Code that are also considered to be very comprehensive as the PLCs should be able to demonstrate four styles of leadership components to represent good governance practiced. This scoring index describes the importance of the Senior Independent Director's position which focuses on the board members' leadership issues.

\section{Discussion and Directions for Future Research}

The before and after analysis research of the 2017 Code, taking into account how the position of the Senior Independent Director developed during the MCCG 2012 era through Board Effectiveness and Board Leadership compared to the MCCG 2017 period was only limited across the Top 100 PLCs within Bursa Malaysia.

In terms of the aftermath of the Covid-19 pandemic, which also has a profound influence on the economy, future studies should look into the implications of the dual catastrophe. The 
Covid-19 pandemic, which has affected all countries around the world in terms of health and economic crisis, combined into one, has resulted in the collapse of companies and potential researchers may want to discover a more in-depth and stronger position for the Senior Independent Director.

\section{References}

Acharya, V. V., \& Johnson, T. C. (2010). More insiders, more insider trading: Evidence from private-equity buyouts. Journal of Financial Economics, 98(3), 500-523. https://doi.org/10.1016/j.jfineco.2010.08.002

Adams, R. B., \& Ferreira, D. (2007). A theory of friendly boards. The Journal of Finance, 62(1), 217-250. https://doi.org/10.1111/j.1540-6261.2007.01206.x

Adams, R. B., Ragunathan, V., \& Tumarkin, R. (2015). Death by Committee? An Analysis of Delegation in Corporate Boards. Working paper.

Armstrong, C. S., Core, J. E., \& Guay, W. R. (2014). Do independent directors cause improvements in firm transparency? Journal of Financial Economics, 113(3), 383-403. https://doi.org/10.1016/j.jfineco.2014.05.009

Ausubel, L. M. (1990). Insider trading in a rational expectations economy. The American Economic Review, 1022-1041.

Beneish, M. D., Marshall, C. D., \& Yang, J. (2016). Explaining CEO retention in misreporting firms. Journal of Financial Economics, forthcoming. https://doi.org/10.1016/j.jfineco.2016.12.004

Bettis, J. C., Coles, J. L., \& Lemmon, M. L. (2000). Corporate policies restricting trading by insiders. Journal of Financial Economics, 57(2), 191-220. https://doi.org/10.1016/S0304-405X(00)00055-6

Bhattacharya, U. (2014). Insider Trading Controversies: A Literature Review. In Lo, A. and R. Merton (ed.) Annual Reviews of Financial Economics, 6, 385-403. https://doi.org/10.1146/annurev-financial-110613-034422

Bris, A. (2005). Do insider trading laws work?. European Financial Management, 11(3), 267-312. https://doi.org/10.1111/j.1354-7798.2005.00285.x

Brochet, F. (2010). Information content of insider trades before and after the Sarbanes-Oxley Act. The Accounting Review, 85(2), 419-446. https://doi.org/10.2308/accr.2010.85.2.419

Buchanan, B. (1974). Building organizational commitment: The socialization of managers in work organizations. Administrative science quarterly, 533-546. https://doi.org/10.2307/2391809

Bursa Malaysia. (2017). Corporate Governance Guide, Pull-out 1, Guidance on board leadership and effectiveness, Kuala Lumpur, Malaysia. 


\section{$\triangle$ Macrothink}

Chen, X., Cheng, Q., \& Wang, X. (2015). Does increased board independence reduce earnings management? Evidence from recent regulatory reforms. Review of Accounting Studies, 20(2), 899-933. https://doi.org/10.1007/s11142-015-9316-0

Cheng, Q., \& Lo, K. (2006). Insider trading and voluntary disclosures. Journal of accounting research, 44(5), 815-848. https://doi.org/10.1111/j.1475-679X.2006.00222.x

Choy, H. L., \& Silvers, R. N. (2009). The Effect of Firm-Imposed Insider Trading Restrictions on Cost of Equity Capital. Available at SSRN 1325387.

Clarke, J., Dunbar, C., \& Kahl, K. (2001). Long-run performance and insider trading in completed and canceled seasoned equity offerings. Journal of Financial and Quantitative Analysis, 36, 415-430. https://doi.org/10.2307/2676218

Cohen, L., Frazzini, A., \& Malloy, C. (2012). Hiring cheerleaders: Board appointments of “independent" directors. Management Science, 58(6), 1039-1058. https://doi.org/10.1287/mnsc.1110.1483

Cohen, L., Malloy, C., \& Pomorski, L. (2012). Decoding inside information. The Journal of Finance, 67(3), 1009-1043. https://doi.org/10.1111/j.1540-6261.2012.01740.x

Coles, J. L., Daniel, D. N., \& Naveen, L. (2015). Director overlap: Groupthink versus teamwork. University of Utah, Working Paper.

Coles, J. L., Daniel, N. D., \& Naveen, L. (2014). Co-opted boards. Review of Financial Studies, 27(6), 1751-1796. https://doi.org/10.1093/rfs/hhu011

Cziraki, P., De Goeij, P., \& Renneboog, L. (2013). Corporate governance rules and insider trading profits. Review of Finance, rft001. https://doi.org/10.1093/rof/rft001

Dai, L., Fu, R., Kang, J. K., \& Lee, I. (2016).Corporate Governance and the Profitability of Insider Trading. Journal of Corporate Finance, Forthcoming https://doi.org/10.1016/j.jcorpfin.2016.08.002

Duchin, R., Matsusaka, J. G., \& Ozbas, O. (2010). When are outside directors effective?. Journal of financial economics, 96(2), 195-214. https://doi.org/10.1016/j.jfineco.2009.12.004

Easley, D., \& O'hara, M. (2004). Information and the cost of capital. The journal of finance, 59(4), 1553-1583. https://doi.org/10.1111/j.1540-6261.2004.00672.x

Easley, D., Hvidkjaer, S., \& O'hara, M. (2002). Is information risk a determinant of asset returns?. The journal of finance, 57(5), 2185-2221. https://doi.org/10.1111/1540-6261.00493

Eckbo, B. E., Nygaard, K., \& Thorburn, K. S. (2016). Does gender-balancing the board reduce firm value?. Tuck School of Business Working Paper, (2746786).

Fich, E. M., \& Shivdasani, A. (2006). Are busy boards effective monitors?. The Journal of finance, 61(2), 689-724. https://doi.org/10.1111/j.1540-6261.2006.00852.x 
Field, L., Lowry, M., \& Mkrtchyan, A. (2013). Are busy boards detrimental?. Journal of Financial Economics, 109(1), 63-82. https://doi.org/10.1016/j.jfineco.2013.02.004

Fos, V., Li, K., \& Tsoutsoura, M. (2016). Do Director Elections Matter?. https://doi.org/10.2139/ssrn.2609815

Fracassi, C., \& Tate, G. (2012). External networking and internal firm governance. The Journal of Finance, 67(1), 153-194. https://doi.org/10.1111/j.1540-6261.2011.01706.x

Francis, T., \& Lublin, J. S. (2016). Big investors question corporate board tenures. The Wall Street Journal, March 23, 2016.

Giannetti, M., \& Zhao, M. (2015). Board Diversity and Firm Performance Volatility. https://doi.org/10.2139/ssrn.2700058

Guo, L., \& Masulis, R. W. (2015). Board structure and monitoring: New evidence from CEO turnovers. Review of Financial Studies, 28(10), 2770-2811. https://doi.org/10.1093/rfs/hhv038

Harris, M., \& Raviv, A. (2008). A theory of board control and size. Review of Financial Studies, 21, 1797-1832. https://doi.org/10.1093/rfs/hhl030

Hermalin, B. E., \& Weisbach, M. S. (1998). Endogenously chosen boards of directors and their monitoring of the CEO. American Economic Review, 88, 96-118.

Hermalin, B. E., \& Weisbach, M. S. (2003). Boards of directors as an endogenously determined institution: A survey of the economic literature. Economic Policy Review (Federal Reserve Board of New York) (April) 7-26.

Horowitz, R. A., \& Bitar, K. Y. (1998). Minimizing the risk of insider trading liability. Client Alert, July, 1(3).

Hu, J., \& Noe, T. H. (2001). Insider Trading and Managerial Incentives. Journal of Banking and Finance, 25, 681-716. https://doi.org/10.1016/S0378-4266(00)00098-4

Huang, S. (2013). Zombie boards: Board tenure and firm performance. https://doi.org/10.2139/ssrn.2302917

Huddart, S. J., \& Ke, B. (2007). Information asymmetry and cross-sectional variation in insider trading. Contemporary Accounting Research, 24(1), 195-232. https://doi.org/10.1506/0277-1110 4434-M627

Hwang, B. H., \& Kim, S. (2009). It pays to have friends. Journal of financial economics, 93(1), 138-158. https://doi.org/10.1016/j.jfineco.2008.07.005

Jaffe, J. F. (1974a). The effect of regulation changes on insider trading. The Bell Journal of Economics and Management Science, 93-121. https://doi.org/10.2307/3003094 
Jaffe, J. F. (1974b). Special information and insider trading. Journal of Business, 47, 410-428. https://doi.org/10.1086/295655

Jagolinzer, A. D. (2009). SEC Rule 10b5-1 and insiders' strategic trade. Management Science, 55(2), 224-239. https://doi.org/10.1287/mnsc.1080.0928

Jagolinzer, A. D., Larcker, D. F., \& Taylor, D. J. (2011). Corporate governance and the information content of insider trades. Journal of Accounting Research, 49(5), 1249-1274. https://doi.org/10.1111/j.1475-679X.2011.00424.x

Jeng, L., Metrick, A., Zeckhauser, R. (2003). Estimating the returns to insider trading: a performance-evaluation perspective. Review of Economics and Statistics, 85, 453-471. https://doi.org/10.1162/003465303765299936

Jenter, D. (2005). Market timing and managerial portfolio decisions. The Journal of Finance, 60(4), 1903-1949. https://doi.org/10.1111/j.1540-6261.2005.00783.x

Jiang, W., Wan, H., \& Zhao, S. (2015). Reputation concerns of independent directors: Evidence from individual director voting. Review of Financial Studies, hhv125. https://doi.org/10.1093/rfs/hhv125

John, K., \& Lang, L. H. (1991). Insider trading around dividend announcements: theory and evidence. The Journal of Finance, 46(4), 1361-1389. https://doi.org/10.1111/j.1540-6261.1991.tb04621.x

Kahle, K. (2000). Insider trading and the long-run performance of new security issues. Journal of Corporate Finance, 6, 25-53. https://doi.org/10.1016/S0929-1199(99)00015-2

Karpoff, J. M., \& Lee, D. (1991). Insider trading before new issue announcements. Financial Management, 18-26. https://doi.org/10.2307/3666093

Katz, R. (1982). The effects of group longevity on project communication and performance. Administrative science quarterly, 81-104. https://doi.org/10.2307/2392547

Ke, B., Huddart, S., Petroni, K. (2003). What insiders know about future earnings and how they use it: evidence from insider trades? Journal of Accounting and Economics, 35, 315-346. https://doi.org/10.1016/S0165-4101(03)00036-3

Khanna, N., Slezak, S. L., \& Bradley, M. (1994). Insider trading, outside search, and resource allocation: why firms and society may disagree on insider trading restrictions. Review of Financial Studies, 7(3), 575-608. https://doi.org/10.1093/rfs/7.3.575

Lakonishok, J., \& Lee, I. (2001). Are insider trades informative? Review of financial studies, 14(1), 79-111. https://doi.org/10.1093/rfs/14.1.79

Lee, D. S., Mikkelson, W. H., \& Partch, M. M. (1992). Managers' trading around stock repurchases. The Journal of Finance, 47(5), 1947-1962. https://doi.org/10.1111/j.1540-6261.1992.tb04690.x 
Leland, H. (1992). Insider trading, should it be prohibited?. Journal of Political Economy, 100, 859-887. https://doi.org/10.1086/261843

Lin, J., \& Howe, J. (1990). Insider trading in the OTC market. Journal of Finance, 45, 1273 1284. https://doi.org/10.1111/j.1540-6261.1990.tb02436.x

Lublin, J. S. (2013). The 40-Year Club: America's Longest-Serving Directors. The Wall Street Journal, July 16, 2013.

Manove, M. (1989). The harm from insider trading and informed speculation. The Quarterly Journal of Economics, 823-845. https://doi.org/10.2307/2937869

Marin, J., \& Olivier, J. (2008). The dog that did not bark: insider trading and crashes. Journal of Finance, 63, 2429-2476. https://doi.org/10.1111/j.1540-6261.2008.01401.x

Masson, R. T., \& Madhavan, A. (1991). Insider Trading and the Value of the Firm. The Journal of Industrial Economics, 333-353. https://doi.org/10.2307/2098435

Masulis, R. W., \& Mobbs, S. (2011). Are all inside directors the same? Evidence from the external directorship market. The Journal of Finance, 66(3), 823-872. https://doi.org/10.1111/j.1540-6261.2011.01653.x

Meulbroek, L. K. (1992). An empirical analysis of illegal insider trading. The Journal of Finance, 47(5), 1661-1699. https://doi.org/10.1111/j.1540-6261.1992.tb04679.x

Niessner, M. (2015). Strategic disclosure timing and insider trading. Unpublished working paper, Yale University. https://doi.org/10.2139/ssrn.2439040

Piotroski, J., \& Roulstone, D. (2005). Do insider trades reflect both contrarian beliefs and superior knowledge about future cash flow realizations? Journal of Accounting and Economics, 39, 55-81. https://doi.org/10.1016/j.jacceco.2004.01.003

Raheja, C. G. (2005). Determinants of board size and composition: A theory of corporate boards. Journal of Financial and Quantitative Analysis, 40, 283-306. https://doi.org/10.1017/S0022109000002313

Ravina, E., \& Sapienza, P. (2010). What do independent directors know? Evidence from their trading. Review of Financial Studies, 23(3), 962-1003. https://oi.org/10.1093/rfs/hhp027 Rogers, J. L., \& Stocken, P. C. (2005). Credibility of management forecasts. The Accounting Review, 80(4), 1233-1260. https://doi.org/10.2308/accr.2005.80.4.1233

Roulstone, D. T. (2003). The relation between insider-trading restrictions and executive compensation. Journal of Accounting Research, 41(3), 525-551. https://doi.org/10.1111/1475-679X.00115

Securities Commission Malaysia. (2012). Malaysian Corporate Code of Corporate Governance 2012, Kuala Lumpur, Malaysia.

Securities Commission Malaysia. (2017). Malaysian Corporate Code of Corporate 
Governance 2017, Kuala Lumpur, Malaysia.

Securities Commission Malaysia. (2018). Corporate Governance Strategic Priorities 2017 2020, Kuala Lumpur, Malaysia.

Seyhun, H. N. (1986). Insiders' profits, costs of trading, and market efficiency. Journal of Financial Economics, 61, 189-212. https://doi.org/10.1016/0304-405X(86)90060-7

Seyhun, H. N. (1990). Overreaction or fundamentals: Some lessons from insiders' response to the market crash of 1987. The Journal of Finance, 45(5), 1363-1388. https://doi.org/10.1111/j.1540-6261.1990.tb03719.x

Seyhun, H. N. (1992). Effectiveness of the Insider-Trading Sanctions. Journal of Law \& Economics, 35(1), 149-182. https://doi.org/10.1086/467248

Seyhun, H. N., \& Bradley, M. (1997). Corporate Bankruptcy and Insider Trading. The Journal of Business, 70(2), 189-216. https://doi.org/10.1086/209715

Skaife, H. A., Veenman, D., \& Wangerin, D. (2013). Internal control over financial reporting and managerial rent extraction: Evidence from the profitability of insider trading. Journal of Accounting and Economics, 55(1), 91-110. https://doi.org/10.1016/j.jacceco.2012.07.005

Stein, M. L. (2016). Investors question independence of long-stay directors. The Wall Street Journal, February 23, 2016.

Summers, S. L., \& Sweeney, J. T. (1998). Fraudulently misstated financial statements and insider trading: An empirical analysis. Accounting Review, 131-146.

Vafeas, N. (1999). Board meeting frequency and firm performance. Journal of financial economics, 53(1), 113-142. https://doi.org/10.1016/S0304-405X(99)00018-5

Vafeas, N. (2003). Length of board tenure and outside director independence. Journal of Business Finance \& Accounting, 30 (7 - 8), 1043-1064. https://doi.org/10.1111/1468-5957.05525

Vance, S. C. (1983). Corporate leadership: Boards, directors, and strategy. McGraw-Hill Companies.

Vekshin, A. (2015). Calpers pushes boards to clear room for the young and ethnic. Bloomberg Politics, November 12, 2015.

$\mathrm{Wu}, \mathrm{W}$. (2016). Information asymmetry and insider trading. Unpublished working paper, Texas A\&M University.

\section{Copyright}

Copyright for this article is retained by the author(s), with first publication rights granted to the journal.

This is an open-access article distributed under the terms and conditions of the Creative Commons Attribution license (http://creativecommons.org/licenses/by/4.0/). 